\title{
Effects of Antagonist Cell Concentration and Two-Strain Mixtures on Biological Control of Fusarium Dry Rot of Potatoes
}

\author{
D. A. Schisler, P. J. Slininger, and R. J. Bothast
}

Fermentation Biochemistry Research, National Center for Agricultural Utilization Research, U.S. Department of Agriculture, Agricultural Research Service, Peoria, IL 61604.

Accepted 7 November 1996.

\begin{abstract}
Schisler, D. A., Slininger, P. J., and Bothast, R. J. 1997. Effects of antagonist cell concentration and two-strain mixtures on biological control of Fusarium dry rot of potatoes. Phytopathology 87:177-183.

Eighteen bacterial strains were individually assayed against Gibberella pulicaris $\left(5 \times 10^{5}\right.$ conidia per $\left.\mathrm{ml}\right)$ by coinoculating antagonist and pathogen in wounds in cv. Russet Burbank potatoes. All antagonist concentrations $\left(10^{6}, 10^{7}\right.$, and $10^{8} \mathrm{CFU} / \mathrm{ml}$ ) decreased disease (38 to $76 \%$ versus control, $P<0.05)$. When four strains were assayed at 11 concentrations (range $10^{5}$ to $10^{8} \mathrm{CFU} / \mathrm{ml}$ ) against G. pulicaris, linear regression of the log-dose, log-response data was significant for all four strains $(P<$ 0.001 to $0.01, R^{2}=0.50$ to 0.74 ). Challenging $G$. pulicaris with all pos-
\end{abstract}

ABSTRACT sible antagonist pairings within 2 sets of 10 antagonist strains $\left(5 \times 10^{5}\right.$ $\mathrm{CFU}$ of each strain per $\mathrm{ml}$ ) resulted in 16 of 90 pairs controlling disease better than predicted based on averaging the performance of the individual strains making up the pair $(P<0.10)$. Successful pairs reduced disease by $\sim 70 \%$ versus controls, a level of control comparable to that obtained with 100 times the inoculum dose of a single antagonist strain. Neither strain genus nor soil of origin were useful in predicting successful antagonist pairs. Factors potentially influencing dose-response relationships and the effectiveness of antagonist pairs in controlling disease are discussed.

Additional keywords: Enterobacter cloacae, Pantoea agglomerans, Pseudomonas corrugata, Pseudomonas fluorescens.
Gibberella pulicaris (Fr.:Fr.) Sacc. (anamorph Fusarium sambucinum Fuckel) is a serious pathogen of potato tubers in storage, where it is the primary causal agent of Fusarium dry rot (1). Crop losses attributed to dry rot have been estimated to average 6\%, with losses up to $25 \%$ reported (6). Of tubers arriving at New York markets between 1972 and 1980, 18\% showed symptoms of Fusarium dry rot (4). In addition to destroying tuber tissues, G. pulicaris can produce trichothecene toxins that have been implicated in mycotoxicoses of humans and animals $(9,38)$. Control alternatives for dry rot of stored potatoes are limited. Resistance to thiabendazole, the only chemical registered for postharvest use on tubers for human consumption, is widespread among field strains of G. pulicaris $(8,13,14,21,37,42)$. Resistance is likely to persist in the field due to the prevalence of vegetative compatibility among North American strains of $G$. pulicaris and the apparent fitness of resistant strains $(7,8)$. All commonly grown potato cultivars are susceptible to Fusarium dry rot (23), and high levels of resistance in breeding stocks are not available (28).

Biological control of postharvest diseases of fruits and vegetables has been effective in numerous studies $(5,19,45)$. The successful development of a microbial antagonist product active against Fusarium dry rot of potatoes is feasible, because G. pulicaris requires wounds to infect, and wounds on potato tubers heal in 5 days to several weeks via the formation of wound periderm (15).

Corresponding author: D. A. Schisler

E-mail address: schislda@ncaur1.ncaur.gov

Names are necessary to report factually on available data; however, the USDA neither guarantees nor warrants the standard of the product, and the use of the name by USDA implies no approval of the product to the exclusion of others that may also be suitable.

Publication no. P-1997-0106-01R

This article is in the public domain and not copyrightable. It may be freely reprinted with customary crediting of the source. The American Phytopathological Society, 1997.
To succeed in suppressing Fusarium dry rot, antagonists would only need to prevent pathogen invasion during this relatively short period of time. Additionally, storage conditions for potato tubers (relative humidities generally greater than $80 \%$ and temperatures ranging from 5 to $15^{\circ} \mathrm{C}$ ) are favorable for growth of many microbial agents. Although yeast strains are rarely effective in controlling this disease (35), 18 bacterial strains have been identified that substantially reduce and sometimes eliminate potato dry rot development incited by G. pulicaris (36).

The relationship between antagonist inoculum dose and the level of disease control realized remains to be determined for any of the antagonists active against dry rot. Such information represents a critical step in accurately evaluating the economics of producing a biocontrol product and predicting the level of control realized when using decreasing numbers of antagonist cells against Fusarium dry rot. Raaijmakers et al. (31) demonstrated the existence of a threshold level of antagonist inoculum below which large changes in disease control resulted from small decreases in antagonist dose. It is not known whether similar thresholds exist for log-dose, logdisease response curves of dry rot antagonists.

The feasibility of producing an economical biocontrol product would be improved further if techniques were devised that enabled significantly fewer antagonist cells to be utilized without substantially reducing the level of disease control realized. One approach that may accomplish this goal would be to evaluate pairs of microbial strains, each at a dose considerably less than employed when used singly, to identify microbial pairs that give control equivalent to single antagonist strains used at considerably higher cell concentrations. Multiple strain mixtures of microbial agents have been employed with some success against plant pathogens in previous studies $(11,12,17,18,22,24-26,29,39,43)$. These studies have concentrated on determining whether mixtures of antagonists control disease, especially when individual strains of a mixture provide inadequate disease control.

Although multiple strain mixtures are logically defendable based on the fact that they more closely mimic the microbial environ- 
ment present on plant tissues, the commercial development of a multiple-strain mixture product would likely require the development of separate production, stabilization, and formulation protocols for each strain. Additionally, strains of a mixture would likely have to be produced and registered separately. Thus, economic incentive favors minimizing the number of strains in a mixture. The current study concentrates on identifying two-strain mixtures of antagonists that are effective at low dosage in controlling disease. The likelihood of discovering pairs of antagonists that would effectively biologically control Fusarium dry rot is considerable, because all microbial antagonists effective against Fusarium dry rot produce antibiotic compounds, and many strains differ substantially in the profiles of compounds produced (3). Complimentary antibiotic production by strains making up an antagonist pair could result in increased effectiveness against individual strains of G. pulicaris and a broader spectrum of postharvest pathogens of potatoes.

The purpose of the current study was to determine the relationship between the dose of 18 potato dry rot antagonists and the level of disease control realized. For selected strains of antagonists, small incremental changes in antagonist concentration were used to further clarify the dose-response relationship. An additional purpose of this study was to evaluate a large number of antagonist pairings using a reduced inoculum dose with the objective of discovering antagonist pairs that control disease to an extent comparable to that realized with higher numbers of cells of individual antagonist strains. Antagonist pairs that controlled Fusarium dry rot to a greater level than predicted were characterized by the taxonomic grouping and soil of origin of the strains making up the pair to determine whether such characteristics could be useful in predicting additional successful antagonist pairings.

\section{MATERIALS AND METHODS}

Bioassays of bacterial antagonists against Fusarium dry rot. Eighteen gram-negative bacterial strains (Table 1), or selected strains from this group, were used. These strains have been dem-

TABLE 1. Identity of bacterial strains that control Fusarium dry rot disease development in potato tubers

\begin{tabular}{|c|c|c|}
\hline Strain & $\begin{array}{c}\text { NRRL }^{w} \\
\text { accession no. }\end{array}$ & Identification $^{\mathrm{x}}$ \\
\hline P22:Y:05 & B-21053 & Pseudomonas fluorescens bv. $\mathrm{V}^{\mathrm{y}}$ \\
\hline S09:P:06 & B-21049 & P. corrugata ${ }^{\mathrm{y}}$ \\
\hline S09:P:14 & B-21105 & P. corrugata \\
\hline S09:T:12 & B-21104 & Pantoea sp. \\
\hline S09:T:14 & B-21051 & Pseudomonas corrugata ${ }^{\mathrm{y}}$ \\
\hline S09:Y:08 & B-21128 & P. fluorescens bv. $\mathrm{I}^{\mathrm{z}}$ \\
\hline S09:P:08 & B-21129 & P. corrugata \\
\hline S09:T:04 & B-21103 & Enterobacter sp. \\
\hline S09:T:10 & B-21101 & Enterobacter sp. \\
\hline S11:P:08 & B-21132 & Enterobacter sp. \\
\hline S11:P:12 & B-21133 & Pseudomonas fluorescens bv. V \\
\hline S11:P:14 & B-21134 & P. fluorescens bv. V \\
\hline S11:T:06 & B-21135 & P. fluorescens bv. V \\
\hline S11:P:02 & B-21136 & P. corrugata \\
\hline S11:T:04 & B-21048 & Pantoea agglomerans $\mathrm{z}^{\mathrm{z}}$ \\
\hline S11:T:07 & B-21050 & Enterobacter cloacae ${ }^{\mathrm{z}}$ \\
\hline S22:T:04 & B-21102 & Pseudomonas fluorescens bv. I \\
\hline S22:T:10 & B-21137 & P. fluorescens bv. V \\
\hline
\end{tabular}

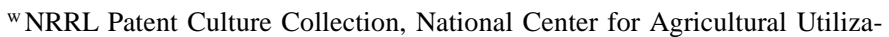
tion Research, Peoria, IL.

${ }^{x}$ Bacterial strains preliminarily identified by Biolog GN microplates and gaschromatographic analysis of phospholipid fatty acids. Presumptive identifications confirmed by published biochemical and physiological tests of taxonomic utility as previously described (36).

y Identification confirmed by the LMG Culture Collection (Belgian Coordinated Collections of Microorganisms, Laboratory of Microbiology, University of Gent), Ghent, Belgium.

${ }^{\mathrm{z}}$ Identification confirmed by the American Type Culture Collection, Rockville, MD. onstrated previously to be effective in suppression of Fusarium dry rot of potato tubers (36). All bacterial strains were originally isolated from gamma irradiation-sterilized field soil samples that had been enriched with potato tuber periderm, inoculated with soils obtained from potato-growing regions in Wisconsin, and found to be suppressive to Fusarium dry rot disease development.

Potato (Solanum tuberosum L. 'Russet Burbank') tubers, obtained from commercial suppliers of seed potatoes, were utilized in all trials. Tubers were stored at $8^{\circ} \mathrm{C}$. Twenty-four hours before use, tubers were gently washed in deionized water and allowed to warm to $20^{\circ} \mathrm{C}$. A suspension of macroconidia of G. pulicaris R-6380 (deposited at the Fusarium Research Center, The Pennsylvania State University, University Park) was produced as described elsewhere (9), except that conidia were suspended in $4{ }^{\circ} \mathrm{C} \mathrm{PO}_{4}$ buffer $(0.004 \%$ phosphate buffer [pH 7.2] with $0.019 \% \mathrm{MgCl}_{2}$; Aid-Pack USA, Gloucester, MA). Bacterial strains were taken from $10 \%$ glycerol, $-80^{\circ} \mathrm{C}$ freezer cultures and streaked onto $1 / 5$-strength tryptic soy broth agar (TSBA/5; Difco Laboratories, Detroit) 2 to 3 days before use. Cultures were restreaked onto TSBA/5 and incubated at $28^{\circ} \mathrm{C}$. Just before use, slightly turbid suspensions of antagonist cells in $4^{\circ} \mathrm{C} \mathrm{PO}_{4}$ buffer were prepared from 18-h-old cultures. Cells grown on solid medium, rather than liquid medium, were utilized because agar-produced cells more consistently maintained CFU counts per milliliter when suspended in liquid and, therefore, could be more accurately adjusted to specific concentrations. Before tuber inoculation, conidial and bacterial suspensions were mixed (1:1) with final concentrations of $5 \times 10^{5}$ conidia per $\mathrm{ml}$ and $1 \times 10^{8} \mathrm{CFU} / \mathrm{ml}$, respectively, unless otherwise noted.

Tubers were inoculated, incubated, harvested, and evaluated for disease symptoms according to methods described by Schisler and Slininger (36). Briefly, tubers were uniformly wounded at four sites spaced at equal distances around the circumference of tubers with a blunted steel nail. Wounds were inoculated with $5 \mu \mathrm{l}$ of a mixed suspension of $G$. pulicaris and a bacterial antagonist. Controls consisted of wounds inoculated with $\mathrm{PO}_{4}$ buffer or suspensions of macroconidia $\left(5 \times 10^{5}\right.$ conidia per $\left.\mathrm{ml}\right)$. Tubers were harvested after 3 weeks of incubation in trays at $15^{\circ} \mathrm{C}$. The extent of disease was evaluated by quartering the tubers longitudinally through each of the four wounds and measuring from a wound site the total depth and width of exposed necrotic tissue. In all trials, there was a total of four replicate wounds per treatment, except for 16 replicate wounds for $G$. pulicaris only controls. The four replicate wounds per treatment occurred once on each of four different potato tubers. Thus, a single tuber contained one replicate wound of each of four treatments. Values from experiments were log-transformed to normalize data when required before statistical analysis. All experiments were conducted twice unless otherwise noted. Data from repeated, identical

TABLE 2. Influence of three antagonist cell concentrations on colonization of cv. Russet Burbank potato tubers by Gibberella pulicaris R-6380

\begin{tabular}{lrr}
\hline \multirow{2}{*}{ Antagonist cell } & \multicolumn{2}{c}{ Colonized tissue $(\mathrm{mm})^{\mathrm{z}}$} \\
\cline { 2 - 3 } concentration $(\mathrm{CFU} / \mathrm{ml})$ & Exp. 1 & Exp. 2 \\
\hline $10^{6}$ & $15.3 \mathrm{~B}$ & $5.4 \mathrm{~B}$ \\
$10^{7}$ & $8.6 \mathrm{C}$ & $4.3 \mathrm{C}$ \\
$10^{8}$ & $6.0 \mathrm{D}$ & $3.9 \mathrm{C}$ \\
0 (R-6380 control) & $24.5 \mathrm{~A}$ & $16.1 \mathrm{~A}$ \\
\hline
\end{tabular}

z Tubers were quartered 21 days after inoculation and incubation at $15^{\circ} \mathrm{C}$ by making longitudinal cuts perpendicular to the tuber surface and through previously inoculated wounds. The sum of the depth and width of the exposed darkened, dry-rotted tissue was determined. Means for antagonist cell concentration are pooled results from four replicate wounds for each of 18 strains of bacterial antagonists. The control value is the mean of 16 replicate wounds. Significant experiment by concentration interaction precluded pooling data from experiments 1 and 2. Within a column, values followed by different letters are significantly different based on Fisher's protected LSD $(P<0.05)$. Analysis of variance and mean comparisons were performed on log-transformed data. The values shown represent back-transformed data. 
experiments were pooled if treatment by experiment interactions were not significant.

Control of $G$. pulicaris R-6380 with three concentrations of 18 bacterial antagonists. Suspensions of all 18 bacterial strains were prepared and adjusted to an absorbance of 0.17 at $620 \mathrm{~nm}$ $\left(\sim 2 \times 10^{8} \mathrm{CFU} / \mathrm{ml}\right)$. A portion of each bacterial suspension was diluted $1 / 10$ and $1 / 100$. A conidial suspension of G. pulicaris R-6380 was prepared with a concentration of $1 \times 10^{6}$ conidia per ml. Equal aliquots of bacterial and conidial suspensions were combined and used to inoculate tubers (final concentration of each microbe was one-half the prepared concentration). A complete factorial design with 3 levels of antagonist concentration and 18 levels of antagonist was employed. Statistical analysis was performed by SAS, version 6.07 (SAS Institute, Cary, NC). Data were log-transformed before analysis of variance (ANOVA) of the $3 \times 18$ factorial data set. Overall concentration and antagonist effects were determined after ANOVA showed that interaction between these factors was not significant. G. pulicaris controls were restored to the database, and the differences between concentration levels or bacterial antagonists and the control were determined by one-way ANOVA. Means were separated by Fisher's protected LSD test. The values reported represent back-transformed data.

Dose-response of dry rot to 11 concentrations of four bacterial antagonists. Results from assays with three concentrations of each bacterial antagonist indicated that selecting several antagonists and evaluating an increased number of dosages of each would permit a more concise relationship between antagonist dose and disease control to be formulated. Bacterial antagonists S22:T:04, S11:T:07, S11:P:08, and S09:Y:08 were selected for detailed study due to their high commercial development ranking (i.e., they possess favorable growth kinetics and biocontrol efficacy when produced in liquid culture media [40]). For each of the antagonists, cell suspensions in $\mathrm{PO}_{4}$ buffer were prepared as described above, and absorbencies were set at 0.170 at $620 \mathrm{~nm}\left(\sim 2 \times 10^{8} \mathrm{CFU} / \mathrm{ml}\right)$. Each suspension was diluted serially by one-half 10 times, such that 11 cell suspensions ranging from $2 \times 10^{8}$ to $2 \times 10^{5} \mathrm{CFU} / \mathrm{ml}$ were prepared. Each antagonist cell suspension was combined 1:1 with a $1 \times 10^{6}$ conidia per ml suspension of G. pulicaris in $\mathrm{PO}_{4}$ buffer. Bacterial cell and conidial mixtures were used to inoculate wounds in tubers (final suspension concentrations of $1 \times 10^{8}$ to $1 \times$ $10^{5} \mathrm{CFU} / \mathrm{ml}$ for bacterial cells and $5 \times 10^{5}$ conidia per $\mathrm{ml}$ for $G$. pulicaris). Disease data (dependent variable) resulting from assays and antagonist concentration (independent variable) were $\log _{10}$ transformed before dose-response models were constructed for each antagonist. Values for $R^{2}$ were calculated based on treatment means.

Dry rot control with pairs of antagonists. For the first set of replicated experiments, 10 antagonist strains were selected at random from the 18 available strains and paired in all possible combinations for assay against $G$. pulicaris (45 different treatment pairs). Bacterial and conidial suspensions were prepared separately as described earlier and combined to form suspensions containing cells of each of the antagonists making up a pair $\left(5 \times 10^{5} \mathrm{CFU}\right.$ of each per $\mathrm{ml})$ and $G$. pulicaris $\left(5 \times 10^{5}\right.$ conidia per $\left.\mathrm{ml}\right)$. Suspensions containing only one bacterial strain and conidia of G. pulicaris also were prepared (final concentration of $1 \times 10^{6} \mathrm{CFU} / \mathrm{ml}$ and $5 \times 10^{5}$ conidia per $\mathrm{ml}$, respectively). Wounded tubers were inoculated with mixed microbial suspensions. A second set of 10 antagonists composed of the 8 untested strains and 2 strains selected at random from the previously assayed group were paired in all possible combinations and assayed against $G$. pulicaris. In total, 90 antagonist pairs and 18 individual strains were evaluated. Disease was assayed after 3 weeks of incubation as described earlier. ANOVA was performed on contrasts of the predicted versus actual level of disease that occurred when a specific antagonist pair was used. The predicted level of disease was derived by averaging the level of disease that resulted when each antagonist of a pair was assayed individually against $G$. pulicaris. Individual antagonists of pairs that controlled disease better than predicted $(P$
$<0.10)$ were categorized by genus and soil of origin as were strains from pairs that did not achieve enhanced levels of disease protection. Chi-square analysis was used to determine whether antagonist pair genus and soil of origin were useful predictors of antagonist pair performance against dry rot.

\section{RESULTS}

Control of $G$. pulicaris R-6380 with three concentrations of 18 bacterial antagonists. ANOVA revealed that although concentration effects did not significantly interact with antagonist strain effects in either experiment $(P<0.61$ and 0.08 for experiments 1 and 2 , respectively), both concentration and antagonist effects significantly interacted with experiment (concentration by experiment, $P<0.001$; antagonist by experiment, $P<0.04$ ). Thus, overall concentration and antagonist effects were calculated separately for experiments 1 and 2 .

In both experiments, an antagonist dose of $1 \times 10^{8} \mathrm{CFU} / \mathrm{ml}$ was very effective in controlling disease development incited by $G$. pulicaris $\mathrm{R}-6380$, with a $76 \%$ reduction in disease compared to controls for both experiments (Table 2). In experiment 2 , the lowest antagonist concentration assayed $\left(1 \times 10^{6} \mathrm{CFU} / \mathrm{ml}\right)$ was more effective in controlling disease $(66 \%$ reduction versus $G$. pulicaris control) than was found in experiment 1 (38\% reduction versus $G$. pulicaris). Disease control significantly differed depending on antagonist dose in experiment 1 , whereas a dose of $10^{7}$ or $10^{8} \mathrm{CFU} /$ $\mathrm{ml}$ did not differ in effect on disease control in experiment 2.

Depending on the experiment, individual antagonists sometimes differed in their overall effect, but generally, antagonists significantly decreased the level of disease incited by G. pulicaris (Table 3 ). In experiment 1,15 of 18 antagonists significantly decreased disease compared to the control $(P<0.01)$, whereas 16 of 18 antagonists controlled disease at the $P<0.05$ level. All 18 antagonists decreased disease at the $P<0.01$ level in experiment 2 (Table 3). The percent reduction in disease when using antagonists ranged from 40 to $77 \%$ in experiment 1 and 63 to $78 \%$ in experiment 2 .

TABLE 3. Influence of 18 bacterial antagonists on symptom development in potato tubers colonized by Gibberella pulicaris R-6380

\begin{tabular}{lcc}
\hline & \multicolumn{2}{c}{ Colonized tissue $(\mathrm{mm})^{\mathrm{y}}$} \\
\cline { 2 - 3 } Bacterial strain & Exp. 1 & Exp. 2 \\
\hline P22:Y:05 & $9.4^{* * \mathrm{z}}$ & $3.8^{* *}$ \\
S09:P:06 & $9.0^{* *}$ & $3.9^{* *}$ \\
S09:P:14 & $9.2^{* *}$ & $5.9 * *$ \\
S09:T:12 & $8.3^{* *}$ & $3.8^{* *}$ \\
S09:T:14 & $6.6^{* *}$ & $4.5^{* *}$ \\
S09:Y:08 & $6.5^{* *}$ & $4.1^{* *}$ \\
S09:P:08 & $8.0^{* *}$ & $5.7^{* *}$ \\
S09:T:04 & $5.6^{* *}$ & $5.1^{* *}$ \\
S09:T:10 & $8.2^{* *}$ & $4.1^{* *}$ \\
S11:P:08 & $9.9^{* *}$ & $3.5^{* *}$ \\
S11:P:12 & $9.7^{* *}$ & $5.0^{* *}$ \\
S11:P:14 & $9.5^{* *}$ & $3.9^{* *}$ \\
S11:T:06 & 14.4 & $4.3^{* *}$ \\
S11:P:02 & 14.6 & $4.1^{* *}$ \\
S11:T:04 & $9.1^{* *}$ & $4.9^{* *}$ \\
S11:T:07 & $12.2^{*}$ & $4.2^{* *}$ \\
S22:T:04 & $9.8^{* *}$ & $4.0^{* *}$ \\
S22:T:10 & $10.3^{* *}$ & $4.5^{* *}$ \\
None (R-6380 control) & 24.5 & 16.1 \\
\hline
\end{tabular}

y Means for bacterial antagonists are pooled results from four replicate wounds for each of the three cell concentrations used $\left(10^{6}, 10^{7}\right.$, and $\left.10^{8} \mathrm{CFU} / \mathrm{ml}\right)$. The control value is the mean of 16 replicate wounds. Significant experiment by antagonist interaction precluded pooling data from experiments 1 and 2 .

${ }^{\mathrm{z}}$ Within a column, values followed by one or two asterisks are significantly different from the control based on Fisher's protected LSD $(P<0.05$ and 0.01 , respectively). Analysis of variance and mean comparisons were performed on log-transformed data. The values shown represent back-transformed data. 
Dose-response of dry rot to 11 concentrations of four bacterial antagonists. ANOVA determined that for only one of the four antagonists (S22:T:04) experiment by concentration interaction was significant $(P<0.03)$. A plot of data obtained in experiments with S22:T:04 revealed that data from one concentration level accounted for the significance of the interaction. Data from both experiments, therefore, was pooled for each of the four antagonists, and dose-response curves were determined. Linear models provided the best fit of the relationship between log antagonist dose and $\log$ diseased tissue for each antagonist over the concentrations tested (Fig. 1A through D).

Linear regression of the dose-response data of S22:T:04, S11:T:07, S11:P:08, and S09:Y:08 was significant at $P<0.01$ for S22:T:04 and at $P<0.001$ for the other three antagonists. Where $y$ is defined as $\log _{10}$ diseased potato tissue (millimeters) and $x$ is defined as $\log _{10}$ bacterial antagonist concentration (CFU per milliliter), the respective dose-response models for S22:T:04, S11:T:07, S11:P:08, and S09:Y:08 are $y=2.11-0.13 x\left(R^{2}=0.50\right) ; y=2.27-0.18 x$ $\left(R^{2}=0.73\right) ; y=2.35-0.20 x\left(R^{2}=0.71\right)$; and $y=2.50-0.21 x\left(R^{2}=\right.$ 0.74 ), respectively (Fig. 1). A dose of 0 antagonist (corresponding $\log$ disease value of 1.49) was not included in the models.

Dry rot control with pairs of antagonists. Because ANOVA did not reveal significant antagonist pair by experiment interactions for either set of antagonists, data from each replicated experiment were pooled. A total of 16 of 90 pairs of antagonists controlled dry rot better than predicted from the level of control obtained by each strain making up the pair (Table 4). Coinoculation with strains P22:Y:05 and S22:T:04, for instance, resulted in only $8.7 \mathrm{~mm}$ of diseased tissue, whereas the same total number of cells of each strain inoculated individually resulted in 20.9 and $18.8 \mathrm{~mm}$ of diseased tissue, respectively. The level of disease control realized when coinoculating with these strains was significantly less $(P$ $<0.01)$ than the predicted result $(19.8 \mathrm{~mm})$ and $71 \%$ less than the G. pulicaris control (Fig. 2). Effective antagonist pairs controlled disease 40 to $69 \%$ better than predicted based on the performance of the strains making up the pairs and reduced disease by 54 to $85 \%$ compared to G. pulicaris controls (Table 4). On average, effective pairs decreased disease by $\sim 50 \%$ compared to the predicted level and by $\sim 70 \%$ compared to G. pulicaris controls (Table 5).

The 18 bacterial antagonists used in this study were isolated from three different soils (S09, S11, and S22). For antagonist pairs isolated from the same soil, 7 of 33 pairs controlled disease better than predicted, whereas 9 of 57 pairs consisting of strains isolated from different soils controlled disease better in dual versus single inoculation. Chi-square analysis $(P<0.05)$ determined that these ratios did not differ, demonstrating that antagonist pairs consisting of strains with the same soil of origin did not have an increased likelihood of enhanced disease control capability. Seven of forty-four pairs composed of coinoculants of the same genus controlled disease better than predicted, whereas nine of forty-six pairs composed of coinoculants of differing genera controlled disease better than predicted. These ratios do not differ according to chi-square analysis $(P<0.05)$. Pairs of antagonists of the same genus, therefore, were no more likely to exhibit enhanced disease control than were pairs made up of antagonists of differing genera.
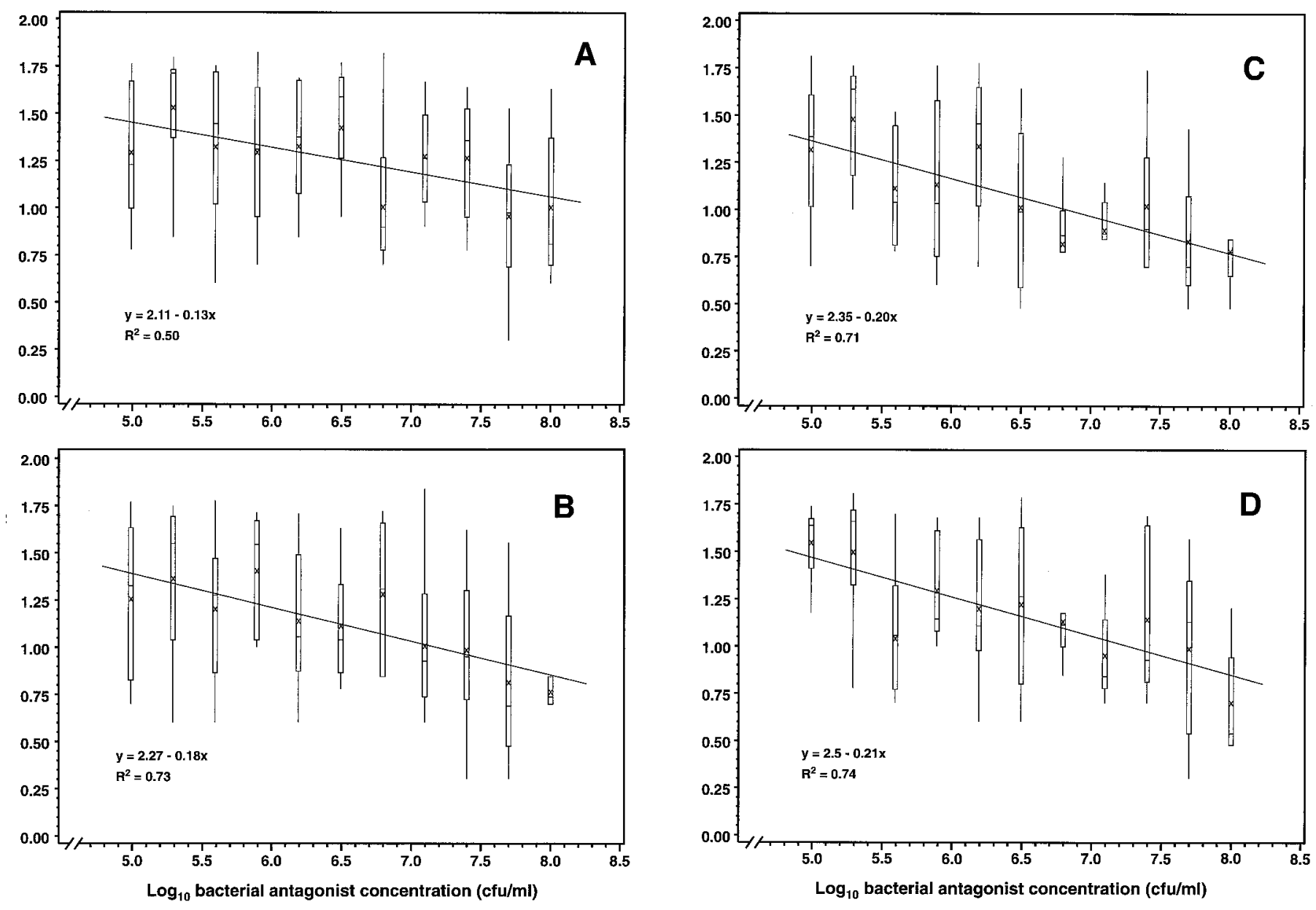

Fig. 1. Linear regression of $\log _{10}$ of Fusarium dry rot-diseased potato tuber tissue (millimeters) versus $\log _{10}$ bacterial antagonist concentration (CFU per milliliter) for four antagonists: A, S22:T:04, B, S11:T:07, C, S11:P:08, and D, S09:Y:08. For each bacterial concentration, top and bottom edges of boxes represent 75th and 25th percentile of ordered values, respectively. Maximum and minimum values observed are shown at ends of "whiskers." Within a box, the median observed value and the mean are indicated by a - and $\times$, respectively. 


\section{DISCUSSION}

In experiments on dose-response with all 18 bacterial antagonists of Fusarium dry rot, doses of $1 \times 10^{8} \mathrm{CFU} / \mathrm{ml}$ proved effective in controlling the disease, whereas less, but still significant, control was demonstrated at cell concentrations of $1 \times 10^{7}$ and $1 \times 10^{6} \mathrm{CFU} / \mathrm{ml}$. With rare exceptions, all 18 antagonists were effective in controlling dry rot, confirming results from a previous study (36). In a more detailed study of the dose-response relationship with four selected bacterial antagonists, the dose-response relationship was well described by a log-linear model (log disease = $m(\log$ dose $)+b$ ) for all of the antagonists over the 11 step range of concentrations between $1 \times 10^{8}$ and $1 \times 10^{5} \mathrm{CFU} / \mathrm{ml}$.

Although our data fit a log-linear relationship of dose-response with antagonist concentrations in the $10^{5}$ to $10^{8} \mathrm{CFU} / \mathrm{ml}$ range tested, most dose-response models predict that at fixed pathogen dose increasing concentrations of antagonist cells will eventually provide a diminishing level of disease control, asymptotically reaching a point where no further disease control is achieved with increasing antagonist dose $(20,27)$. This diminishing return in disease control with increasing antagonist dose likely results from a decreasing amount of pathogen inactivation occurring per unit of biocontrol agent at high biocontrol agent densities $(20,27)$. In repeated experiments (D. A. Schisler, P. J. Slininger, and R. J. Bothast, unpublished data) conducted separately from those reported here, we found that a dose of $10^{9} \mathrm{CFU} / \mathrm{ml}$ (average result of all 18 antagonists) resulted in disease reduction of $70 \%$ compared to controls. Because a dose of $10^{8} \mathrm{CFU} / \mathrm{ml}$ resulted in a $76 \%$ reduction in disease in the current study, it is possible that a dose of $10^{8}$ $\mathrm{CFU} / \mathrm{ml}$ provides close to the maximum level of control achiev-

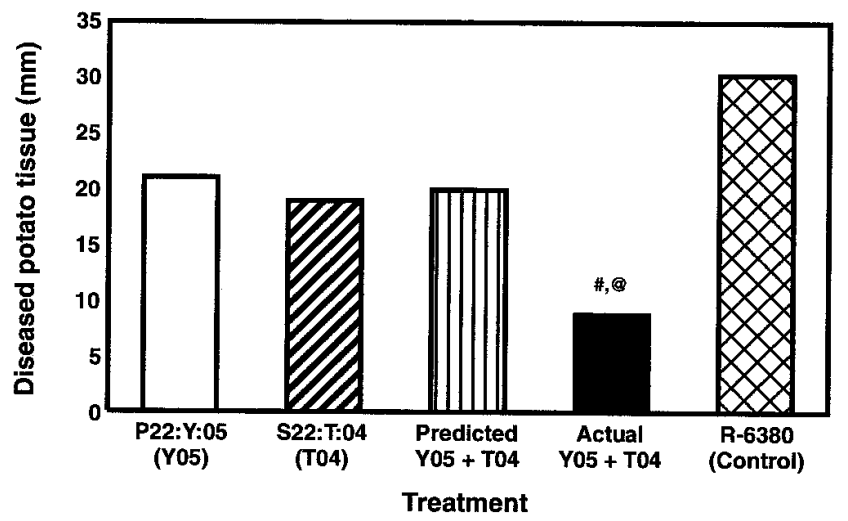

Fig. 2. Comparison of predicted versus actual control of Gibberella pulicaris R-6380 on potato tubers with a mixture of two strains of bacterial antagonists. An identical number of cells $\left(1 \times 10^{6} \mathrm{CFU} / \mathrm{ml}\right)$ of either strain P22:Y:05 (abbreviated Y05) or S22:T:04 (abbreviated T04) or a mixture of both (abbreviated Y05 + T04, total cells equal $1 \times 10^{6} \mathrm{CFU} / \mathrm{ml}$ ) were utilized against the pathogen. Predicted performance of the antagonist pair is the arithmetic mean of the actual performance of the individual strains making up the pair. \# indicates significantly different from predicted result (contrast significant at $P<0.01$ ). @ indicates significantly different from G. pulicaris $\mathrm{R}-6380$ control based on Fisher's protected LSD $(P<0.001)$.
TABLE 4. Bacterial antagonist pairs ${ }^{\mathrm{v}}$ exhibiting enhanced control of Gibberella pulicaris $\mathrm{R}-6380$ on potato tubers

\begin{tabular}{|c|c|c|c|c|c|}
\hline \multirow[b]{2}{*}{$\begin{array}{l}\text { Antagonist } \\
\text { pair }^{\mathrm{w}}\end{array}$} & \multicolumn{2}{|c|}{ Disease $^{\mathrm{x}}$} & \multicolumn{2}{|c|}{$\%$ Disease decrease } & \multirow{2}{*}{$\begin{array}{c}P^{\mathrm{x}} \\
(\text { actual }< \\
\text { predicted) }\end{array}$} \\
\hline & $\begin{array}{l}\text { Predicted }{ }^{y} \\
\quad(\mathrm{~mm})\end{array}$ & $\begin{array}{c}\text { Actual } \\
(\mathrm{mm})\end{array}$ & $\begin{array}{c}\text { From } \\
\text { predicted }\end{array}$ & $\begin{array}{c}\text { From } \\
\text { control }^{\mathrm{z}}\end{array}$ & \\
\hline \multicolumn{6}{|l|}{ Set 1} \\
\hline $\begin{array}{l}\text { S09:T:10 } \\
\text { P22:Y:05 }\end{array}$ & 24.5 & 13.6 & 44 & 55 & 0.03 \\
\hline $\begin{array}{l}\text { S09:T:10 } \\
\text { S09:P:06 }\end{array}$ & 26.7 & 13.7 & 49 & 54 & 0.06 \\
\hline $\begin{array}{l}\text { S09:T:10 } \\
\text { S09:T:04 }\end{array}$ & 21.4 & 11.2 & 48 & 63 & 0.05 \\
\hline $\begin{array}{l}\text { S09:T:10 } \\
\text { S11:T:04 }\end{array}$ & 23.2 & 10.7 & 54 & 64 & 0.03 \\
\hline $\begin{array}{l}\text { S09:T:10 } \\
\text { S22:T:04 }\end{array}$ & 23.5 & 12.1 & 49 & 60 & 0.08 \\
\hline $\begin{array}{l}\text { S09:T:10 } \\
\text { S09:P:14 }\end{array}$ & 19.3 & 9.3 & 52 & 69 & 0.03 \\
\hline $\begin{array}{l}\text { P22:Y:05 } \\
\text { S22:T:04 }\end{array}$ & 19.8 & 8.7 & 56 & 71 & 0.01 \\
\hline $\begin{array}{l}\text { S09:P:06 } \\
\text { S09:T:12 }\end{array}$ & 24.7 & 7.7 & 69 & 74 & $<0.01$ \\
\hline $\begin{array}{l}\text { S09:T:12 } \\
\text { S09:T:14 }\end{array}$ & 19.8 & 10.7 & 46 & 64 & 0.03 \\
\hline $\begin{array}{l}\text { S09:T:12 } \\
\text { S11:T:04 }\end{array}$ & 21.2 & 12.6 & 41 & 58 & 0.06 \\
\hline \multicolumn{6}{|l|}{ Set 2} \\
\hline $\begin{array}{l}\text { S09:Y:08 } \\
\text { S11:P:08 }\end{array}$ & 23.5 & 12.6 & 46 & 71 & 0.06 \\
\hline $\begin{array}{l}\text { S09:Y:08 } \\
\text { S11:P:02 }\end{array}$ & 26.6 & 13.4 & 50 & 69 & 0.07 \\
\hline $\begin{array}{l}\text { S11:P:14 } \\
\text { S11:P:02 }\end{array}$ & 22.1 & 8.8 & 60 & 80 & 0.03 \\
\hline $\begin{array}{l}\text { S11:P:02 } \\
\text { S22:T:10 }\end{array}$ & 20.3 & 11.2 & 45 & 74 & 0.09 \\
\hline $\begin{array}{l}\text { S11:P:02 } \\
\text { S09:T:12 }\end{array}$ & 22.6 & 6.5 & 71 & 85 & $<0.01$ \\
\hline $\begin{array}{l}\text { S22:T:10 } \\
\text { S09:T:12 }\end{array}$ & 14.8 & 8.8 & 40 & 80 & 0.09 \\
\hline
\end{tabular}

${ }^{\vee}$ Bacterial antagonists were assayed at a total concentration of $1 \times 10^{6} \mathrm{CFU} / \mathrm{ml}$, with each pair member at $5 \times 10^{5} \mathrm{CFU} / \mathrm{ml}$.

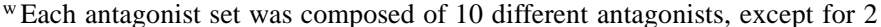
antagonists that were used in both sets.

${ }^{x}$ Contrast of predicted versus actual disease was performed on log-transformed data and was significant at the $P$ value listed. Values for each antagonist set represent pooled results from two experiments and were backtransformed.

${ }^{y}$ The predicted level of control for an antagonist pair was calculated by averaging the control achieved when individually assaying each strain of the pair at $1 \times 10^{6} \mathrm{CFU} / \mathrm{ml}$.

${ }^{z}$ The average disease for the G. pulicaris control for experiments involving antagonist sets 1 and 2 was 30.1 and $43.5 \mathrm{~mm}$, respectively.

TABLE 5. Summary of performance of bacterial antagonist coinoculants ${ }^{\mathrm{w}}$ in controlling Gibberella pulicaris R-6380

\begin{tabular}{|c|c|c|c|c|c|}
\hline & \multicolumn{3}{|c|}{ Combinations } & \multicolumn{2}{|c|}{$\%$ Average disease decrease } \\
\hline & Assayed & $\begin{array}{l}\text { Better disease control } \\
\text { than predicted }(P<0.10)^{\mathrm{x}, \mathrm{y}}\end{array}$ & $\begin{array}{c}\% \\
\text { Significant }\end{array}$ & $\begin{array}{l}\text { From } \\
\text { predicted }\end{array}$ & $\begin{array}{l}\text { From } \\
\text { G. pulicaris }\end{array}$ \\
\hline Antagonist set $1^{z}$ & 45 & 10 & 22 & 50 & 63 \\
\hline Overall totals & 90 & 16 & 18 & 54 & 72 \\
\hline
\end{tabular}

${ }^{\mathrm{w}}$ Bacterial antagonist assayed at a concentration of $1 \times 10^{6} \mathrm{CFU} / \mathrm{ml}$.

${ }^{\mathrm{x}}$ Two of ninety $(2 \%)$ antagonist pairs performed worse than predicted in controlling disease. These pairs had $175 \%$ more disease than predicted but decreased disease versus $\mathrm{R}-6380$ by $33 \%$.

${ }^{y}$ The predicted level of control for a pair of antagonists was calculated by averaging the control achieved when individually assaying each strain of an antagonist pair.

${ }^{\mathrm{z}}$ For each antagonist set, values represent pooled results from two experiments. 
able under the conditions of pathogen dose and environmental parameters used. Studies with small incremental concentration increases in antagonist dose above the level of $10^{8} \mathrm{CFU} / \mathrm{ml}$ used in this study would be needed to determine definitively where the log-dose response curve becomes nonlinear, with progressively less reduction in disease per unit of log-antagonist concentration.

Working with Fusarium wilt of radish, Raaijmakers et al. (31) found a sharp inflection in an antagonist dose disease response plot when bacterial populations on roots dropped below a level that corresponded with an asymptotic, maximal level of disease suppression. Our results may be considered similar in concept if a dose of $\sim 1 \times 10^{8} \mathrm{CFU} / \mathrm{ml}$ provides near maximal disease suppression. It is likely that antagonist doses much lower than those used in the studies with four antagonists would have had not have decreased in disease because the level of disease with no antagonist (i.e., the Gibberella pulicaris R-6380 control, which had a $\log _{10}$ millimeter of diseased tissue value of 1.49) was approximately equivalent to the level of disease seen with our lowest inoculum concentration for each of the four antagonists tested. Thus, our logarithmic dose-response function must become nonlinear and parallel the $\mathrm{x}$-axis at antagonist doses only slightly less than $1 \times 10^{5} \mathrm{CFU} / \mathrm{ml}$.

As graphically demonstrated in our box and whisker plots of diseased tissue versus antagonist dose (Fig. 1A through D), the level of variability frequently encountered in experimentation with biocontrol systems confounds the direct application of results to dose-response theory. Variation in the level of disease incited by G. pulicaris may be explained partially by differences in individual tuber physiology. Interestingly, in a recent study, Pierson et al. (30) determined that phenazine antibiotic production by Pseudomonas aureofaciens $30-84$ is regulated by cell density, with maximal gene expression occurring at high cell densities. Should similarly regulated antibiotic production genes be present in strains utilized in the current study, the highly variable levels of biological control realized with slight changes in antagonist dose may be due, in part, to whether antagonist cells inoculated into wounds subsequently reached population densities adequate to induce genes involved in antibiotic production or other biocontrol functions.

In addition to their utility in driving biocontrol research approaches and interpretations, dose-response models will undoubtedly be of use in developing rate recommendations for product labels and calculating cost analysis for product production. However, even with dose-response models well characterized for various antagonist and pathogen inoculum levels in laboratory settings, direct application of these models for developing recommended label doses is problematic, because pathogen concentration and factors influencing interaction between antagonist and pathogen inoculum will differ greatly at individual sites of product deployment. Pathogen dose and factors influencing the level of pathogen inactivation occurring per unit of biocontrol agent is predicted to radically change resultant dose-response curves $(20,27)$. Additionally, although the microbial cultivation environment $(32,33,40)$ and formulation $(16,34,41)$ can influence microbial function, the influence of these factors on antagonist dose-response has not been studied. Final dose recommendations for biocontrol products, therefore, will be most accurately determined after the composition of large-scale fermentation media and product formulations for commercial use have been finalized.

Mixtures of microbial antagonists have been used successfully to increase the level of biological control above that achieved with individual strains of the mixture $(11,12,17,18,22,24,25,26,29,39$, 43). In our studies, bacterial antagonists were combined at $1 / 100$ the concentration of an effective dose of the individual strains making up the pair. Sixteen pairs of antagonists controlled dry rot development better than predicted based on the performance of the individual strains making up the pairs.

There are several plausible explanations for the synergistic disease control seen with some pairs of antagonists. Although factors such as soil of origin or taxonomic grouping of each isolate of an antagonist pair were not useful in predicting whether the pair would exhibit superior dry rot control, this could be due to the categorizations being too general to identify microbial traits that may act together to enhance disease control. Coexistence and interaction of microbes is the norm in nature. When niche overlap was minimal, different epiphytic bacterial strains exhibited higher levels of coexistence than those with similar niche preferences on bean leaves (46). A portion of this successful coexistence was attributed to compatible strains possessing differing carbon substrate utilization profiles. Janisiewicz (18) demonstrated that combining two antagonists on the basis of niche differentiation increased the chance that the antagonist pair would display improved control of Penicillium expansum on apple fruit. Diverse niches also are likely to be found in potato wounds, which would possibly result in $G$. pulicaris being exposed to higher total bacterial populations and a wider range of nutrient competition when challenged by coexisting mixtures of microbial strains than would be the case with a single inoculant. Determining substrate utilization profiles of strains of antagonist pairs that are successful or unsuccessful in controlling disease would provide further clues as to the nature of the disease control success of some antagonist pairs, as would evaluation of the colonization characteristics of successful and unsuccessful pairs of potato dry rot antagonists.

The success of some antagonist pairs also may be attributable to individual strains of a pair possessing complementary modes of action. Numerous modes of action have been postulated and demonstrated for antagonists effective in controlling postharvest diseases, including nutrient competition, antibiotic production, enzymes that act on fungal cell wall components, such as chitinases and $\beta$ 1,3 glucanase, and induced host resistance $(2,3,10,44,45)$. Results of a study by Lemanceau et al. (26) suggested that antibiotic production by a bacterial antagonist resulted in a pathogenic strain of F. oxysporum being more sensitive to glucose competition from a nonpathogenic $F$. oxysporum. Certainly the wide array of antibiotic compounds produced by the 18 antagonist strains considered in this study (3) support the possibility that complimentary antibiotic production accounts for the biocontrol success of some pairs.

A biocontrol product composed of a mixture of antagonists does have a potential drawback: producing and registering such a product could be more costly in the investment of materials, equipment, and production time than a product composed of a single antagonist. However, in this study, successful antagonist pairs decreased Fusarium dry rot by an average of $\sim 70 \%$, with some pairs decreasing disease by as much as $85 \%$, whereas individual strains utilized at 100 times the cell concentration decreased disease by an average of $75 \%$ compared to controls. Thus, over time the savings from achieving an effective dose with $1 / 100$ the number of antagonist cells may more than offset the added expense of producing a biocontrol product composed of two microbial strains. As with studies concerned with clarifying dose-response curves with these antagonists, final judgment on the economics and feasibility of producing a biocontrol product composed of a mixture of two antagonist strains must await the results of studies to determine the impact of liquid culture nutritional environment and cell formulation on the biocontrol activity of antagonists applied as individuals and in pairs.

\section{ACKNOWLEDGMENTS}

We thank T. Nelsen for statistical guidance; T. Soncasie and J. Ierulli for expert technical assistance; and S. Sylvester and S. Prather for their instrumental role in the development of the figures.

\section{LITERATURE CITED}

1. Boyd, A. E. W. 1972. Potato storage diseases. Rev. Plant Pathol. 51:297321.

2. Burkhead, K. D., Schisler, D. A., and Slininger, P. J. 1994. Pyrrolnitrin production by biological control agent Pseudomonas cepacia $\mathrm{B} 37 \mathrm{w}$ in 
culture and in colonized wounds of potatoes. Appl. Environ. Microbiol. 60:2031-2039.

3. Burkhead, K. D., Schisler, D. A., and Slininger, P. J. 1995. Bioautography shows antibiotic production by soil bacterial isolates antagonistic to fungal dry rot of potatoes. Soil Biol. Biochem. 27:1611-1616.

4. Cappellini, R. A., Ceponis, M. J., Wells, J. M., and Lightner, G. W. 1984. Disorders in potato shipments to the New York market, 1972-1980. Plant Dis. 68:1018-1020.

5. Chalutz, E., and Droby, S. Biological control of postharvest diseases: An overview. In: Plant-Microbe Interaction and Biological Control. G. J. Boland and L. D. Kuykendall, eds. Marcel Dekker, Inc., New York. In press.

6. Chelkowski, J. 1989. Toxinogenicity of Fusarium species causing dry rot of potato tubers. Pages 435-440 in: Fusarium Mycotoxins, Taxonomy and Pathogenicity. J. Chelkowski, ed. Elsevier Publishing Co., New York.

7. Desjardins, A. E. 1995. Population structure of Gibberella pulicaris (anamorph Fusarium sambucinum) from potato tuber dry rot in North America and Europe. Am. Potato J. 72:145-156.

8. Desjardins, A. E., Christ-Harned, E. A., McCormick, S. P., and Secor, G. A. 1993. Population structure and genetic analysis of field resistance to thiabendazole in Gibberella pulicaris from potato tubers. Phytopathology 83:164-170.

9. Desjardins, A. E., and Plattner, R. D. 1989. Trichothecene toxin production by strains of Gibberella pulicaris (Fusarium sambucinum) in liquid culture and in potato tubers. J. Agric. Food Chem. 37:388-392.

10. Droby, S., and Chalutz, E. 1994. Mode of action of biocontrol agents of postharvest diseases. Pages 63-76 in: Biological Control of Postharvest Diseases-Theory and Practice. C. L. Wilson and M. E. Wisniewski, eds. CRC Press, Inc., Boca Raton, FL.

11. Duffy, B. K., Simon, A., and Weller, D. M. 1996. Combination of Trichoderma koningii with fluorescent pseudomonads for control of take-all on wheat. Phytopathology 86:188-194.

12. Duffy, B. K., and Weller, D. M. 1995. Use of Gaeumannomyces graminis var. graminis alone and in combination with fluorescent Pseudomonas spp. to suppress take-all of wheat. Plant Dis. 79:907-911.

13. Hanson, L. E., Schwager, S. J., and Loria, R. 1996. Sensitivity to thiabendazole in Fusarium species associated with dry rot of potato. Phytopathology 86:378-384.

14. Hide, G. A., Read, P. J., and Hall, S. M. 1992. Resistance to thiabendazole in Fusarium species isolated from potato tubers affected by dry rot. Plant Pathol. 41:745-748.

15. Hooker, W. J., ed. 1981. Compendium of Potato Diseases. The American Phytopathological Society, St. Paul, MN.

16. Jackson, M. A., Shasha, B. S., and Schisler, D. A. 1996. Formulation of Colletotrichum truncatum microsclerotia for improved biocontrol of the weed hemp sesbania (Sesbania exaltata). Biol. Control 7:107-113.

17. Janisiewicz, W. J. 1988. Biocontrol of postharvest diseases of apples with antagonist mixtures. Phytopathology 78:194-198.

18. Janisiewicz, W. 1996. Ecological diversity, niche overlap, and coexistence of antagonists used in developing mixtures for biocontrol of postharvest diseases of apples. Phytopathology 86:473-479.

19. Janisiewicz, W. J. Biological control of postharvest diseases of temperate fruits: Challenges and opportunities. In: Plant-Microbe Interaction and Biological Control. G. J. Boland and L. D. Kuykendall, eds. Marcel Dekker, Inc., New York. In press.

20. Johnson, K. B. 1994. Dose-response relationships and inundative biological control. Phytopathology 84:780-784.

21. Kawchuk, L. M., Holley, J. D., Lynch, D. R., and Clear, R. M. 1994. Resistance to thiabendazole and thiophanate-methyl in Canadian isolates of Fusarium sambucinum and Helminthosporium solani. Am. Potato J. 71: 185-192.

22. Kloepper, J. W. 1983. Effect of seed piece inoculation with plant growthpromoting rhizobacteria on populations of Erwinia carotovora on potato roots and daughter tubers. Phytopathology 73:217-219.

23. Leach, S. S., and Webb, R. E. 1981. Resistance of selected potato cultivars and clones to Fusarium dry rot. Phytopathology 71:623-629.

24. Leeman, M., Den Ouden, F. M., Van Pelt, J. A., Cornelissen, C., MatamalaGarros, A., Bakker, P. A. H. M., and Schippers, B. 1996. Suppression of Fusarium wilt of radish by co-inoculation of fluorescent Pseudomonas spp. and root-colonizing fungi. Eur. J. Plant Pathol. 102:21-31.

25. Lemanceau, P., Bakker, P. A. H. M., DeKogel, W. J., Alabouvette, C., and Schippers, B. 1992. Effect of pseudobactin 358 production by Pseudomonas putida WCS358 on suppression of Fusarium wilt of carnations by nonpathogenic Fusarium oxysporum Fo47. Appl. Environ. Microbiol. 58: 2978-2982.

26. Lemanceau, P., Bakker, P. A. H. M., DeKogel, W. J., Alabouvette, C., and Schippers, B. 1993. Antagonistic effect of nonpathogenic Fusarium oxysporum Fo47 and pseudobactin 358 upon pathogenic Fusarium oxysporum f. sp. dianthi. Appl. Environ. Microbiol. 59:74-82.
27. Montesinos, E., and Bonaterra, A. 1996. Dose-response models in biological control of plant pathogens: An empirical verification. Phytopathology 86:464-472.

28. Pawlak, A., Pavek, J. J., and Corsini, D. L. 1987. Resistance to storage diseases in breeding stocks. Pages 96-98 in: The Production of New Potato Varieties: Technological Advances. G. J. Jellis and D. E. Richardson, eds. Cambridge University Press, New York.

29. Pierson, E. A., and Weller, D. M. 1994. Use of mixtures of fluorescent pseudomonads to suppress take-all and improve the growth of wheat. Phytopathology 84:940-947.

30. Pierson, L. S., III, Keppenne, V. D., and Wood, D. W. 1994. Phenazine antibiotic biosynthesis in Pseudomonas aureofaciens 30-84 is regulated by PhzR in response to cell density. J. Bacteriol. 176:3966-3974.

31. Raaijmaker, J. M., Leeman, M., van Oorschot, M. M. P., van der Sluis, I., Schippers, B., and Bakker, P. A. H. M. 1995. Dose-response relationships in biological control of Fusarium wilt of radish by Pseudomonas spp. Phytopathology 85:1075-1081.

32. Schisler, D. A., Burkhead, K. D., Slininger, P. J., and Bothast, R. J. Selection, characterization and use of microbial antagonists for the control of Fusarium dry rot of potatoes. In: Plant-Microbe Interaction and Biological Control. G. J. Boland and L. D. Kuykendall, eds. Marcel Dekker, Inc., New York. In press.

33. Schisler, D. A., Jackson, M. A., and Bothast, R. J. 1991. Influence of nutrition during conidiation of Colletotrichum truncatum on conidial germination and efficacy in inciting disease in Sesbania exaltata. Phytopathology 81:587-590.

34. Schisler, D. A., Jackson, M. A., McGuire, M. R., and Bothast. R. J. 1995. Use of pregelatinized starch and Casamino acids to improve the efficacy of Colletotrichum truncatum conidia produced in differing nutritional environments. Pages 659-664 in: Proc. 8th Int. Symp. Biol. Control Weeds. E. S. Delfosse and R. R. Scott, eds. DSIR/CSIRO, Melbourne, Australia.

35. Schisler, D. A., Kurtzman, C. P., Bothast, R. J., and Slininger, P. J. 1995. Evaluation of yeasts for biological control of Fusarium dry rot of potatoes. Am. Potato J. 72:339-353.

36. Schisler, D. A., and Slininger, P. J. 1994. Selection and performance of bacterial strains for biologically controlling Fusarium dry rot of potatoes incited by Gibberella pulicaris. Plant Dis. 78:251-255.

37. Secor, G. A., Rodriguez, D., Rodriguez, J., and Gudmestad, N. C. 1994. Distribution and incidence of benzimidazole-resistant Fusarium sambucinum and Helminthosporium solani isolated from potato in North America. Pages 271-274 in: BCPC Monograph 60: Fungicide Resistance. British Crop Protection Council, Farnham, England.

38. Senter, L. H., Sanson, D. R., Corley, D. G., Tempesta, M. S., Rottinghaus, A. A., and Rottinghaus, G. E. 1991. Cytotoxicity of trichothecene mycotoxins isolated from Fusarium sporotrichioides (MC-72083) and Fusarium sambucinum in baby hamster kidney (BHK-21) cells. Mycopathologia 113:127-131.

39. Sivasithamparam, K., and Parker, C. A. 1978. Effects of certain isolates of bacteria and actinomycetes on Gaeumannomyces graminis var. tritici and take-all of wheat. Aust. J. Bot. 26:773-782.

40. Slininger, P. J., Schisler, D. A., and Bothast, R. J. 1994. Two-dimensional liquid culture focusing: A method of selecting commercially promising microbial isolates with demonstrated biological control capability. Pages 29-32 in: Improving Plant Productivity with Rhizosphere Bacteria. M. H. Ryder, P. M. Stephens, and G. D. Bowen eds. Graphic Services, Adelaide, Australia.

41. Slininger, P. J., VanCauwenberge, J. E., Bothast, R. J., Weller, D. M., Thomashow, L. S., and Cook, R. J. 1996. Effect of growth culture physiological state, metabolites, and formulation on the viability, phytotoxicity, and efficacy of the take-all biocontrol agent Pseudomonas fluorescens 2-79 stored encapsulated on wheat seeds. Appl. Microbiol. Biotechnol. 45:391-398.

42. Tivoli, B., Deltour, A., Molet, D., Bedin, P., and Jouan, B. 1986. Mise en évidence de souches de Fusarium roseum var. sambucinum resistantes au thiabendazole, isolées à partir de tubercules de pomme de terre. Agronomie 6:219-224.

43. Weller, D. M., and Cook, R. J. 1983. Suppression of take-all of wheat by seed treatments with fluorescent pseudomonads. Phytopathology 73:463469.

44. Wilson, C. L., Ghaouth, A. E., Chalutz, E., Droby, S., Stevens, C., Lu, J. Y., Khan, V., and Arul, J. 1994. Potential of induced resistance to control postharvest diseases of fruits and vegetables. Plant Dis. 78:837-843.

45. Wilson, C. L., and Wisniewski, M. E., eds. 1994. Biological Control of Postharvest Diseases-Theory and Practice. CRC Press, Inc., Boca Raton, FL.

46. Wilson, M., and Lindow, S. E. 1994. Coexistence among epiphytic bacterial populations mediated through nutritional resource partitioning. Appl. Environ. Microbiol. 60:4468-4477. 